\title{
Seed banks of Erica australis and Calluna vulgaris in a heathland subjected to experimental fire
}

\author{
Valbuena, Luz, Tárrega, Reyes \& Luis-Calabuig, Estanislao \\ Area de Ecología, Facultad de Biología, Universidad de León, 24071 León, Spain; \\ Fax+34987291501; E-mail degmvr@isidoro.unileon.es
}

\begin{abstract}
Soil samples were collected before and after an experimental fire on a heathland in the province of León (Spain). The seed banks were assessed by counting the numbers of seedlings appearing of Erica australis and Calluna vulgaris. A total of 2285 germinable seeds $/ \mathrm{m}^{2}$ before burning and 1177 germinable seeds $/ \mathrm{m}^{2}$ after the fire were estimated for Erica australis, and 90 and 690 germinable seeds $/ \mathrm{m}^{2}$, respectively, for Calluna vulgaris. After the fire the number of germinable seeds $/ \mathrm{m}^{2}$ of Erica australis had decreased, whilst there was a considerable increase in the number of germinable seeds $/ \mathrm{m}^{2}$ of Calluna vulgaris. Neither seedlings nor sprouts of Calluna vulgaris had appeared in the field plots 10 months after the fire. Erica australis did recover mainly by sprouting after fire.
\end{abstract}

Keywords: Calluna vulgaris; Erica australis; Experimental fire; Heathland; Recovery; Seed bank.

Nomenclature: Tutin et al. (1964-1980).

\section{Introduction}

Approximately $26 \%$ of the surface of Spain is covered by shrubland, with a considerable diversity in plant communities rang from almost monospecific to those with a large number of species. Shrub and scrubland cover $33 \%$ of the northwest of the Iberian peninsula (León province) where this study was carried out (Anon. 1984). Heathland stands out as the dominant shrub formation, usually being the community with the highest diversity of ligneous species (Luis-Calabuig et al. 1989).

Shrub communities in the Mediterranean Basin are adapted to fire (Naveh 1974; Luis-Calabuig et al. 1987; Trabaud 1987). Various studies on fire in heath communities have been carried out in countries such as Australia (Keith \& Bradstock 1994), and Chile (Jimenez \& Armesto 1992) Scotland in Calluna heathlands (Mallik \& Gimingham 1983; Miller \& Cummins 1987), and in Erica spp. heathlands in Italy (Mazzoleni \& Pizzolongo 1990), and in Spain (García-Novo 1977; Vera \& Obeso 1995). In studies carried out in Israel, Naveh (1974) states that Ericaceae produce vigorous sprouts and also regenerate well via seeds and are therefore dominant in the first succession stages of shrubland. Debussche et al. (1980) also observed significant recovery of ericaceous species by both sprouting and from large numbers of seedlings.

Initial recovery of these species by seed after a fire will depend on the germination capacity of seed population in the soil; this, in turn, may be modified by the temperatures reached during the fire. The number of seeds in the soil as well as those that arrive in a recently burnt area by dispersal will not always be present in post-fire vegetation, but they may play an important role by increasing the genetic heterogeneity of the different species (Belhassen et al. 1987). The seed bank can also stabilize populations by smoothing oscillations in population size in the direction of a state of balance (MacDonald \& Watkinson 1981; Pacala 1986; Lavorel et al. 1991). The soil seed bank can thus have an important role in the regeneration of plant communities on burned areas, being a permanent reserve that ensures community conservation and restoration (Bakker 1989; Trabaud 1994; Thompson et al 1997).

The main purpose of this study is to assess the effect of fire on the seeds of Erica australis and Calluna vulgaris buried in the soil, comparing the germinable seed bank before and after the fire, as well as to determine how the soil seed bank influences recovery of these species.

\section{Methods \\ Site description}

The study site is a shrubland in the province of León province, Spain $\left(42^{\circ} 41^{\prime} \mathrm{N}, 1^{\circ} 25^{\prime} \mathrm{W}\right)$. It is within a wider area that includes grazing land and Quercus pyrenaica / dehesa formations. Shrubland has gradually invaded the area following a reduction in grazing livestock. The study plots were located in a homogeneous heathland, with a height of 1-1.5 m. The dominant species was Erica australis, with a mean biomass of $1 \mathrm{~kg} / \mathrm{m}^{2}$; also abundant was Calluna vulgaris, with $400 \mathrm{~g} / \mathrm{m}^{2}$. The mean above-ground biomass was $1.8 \mathrm{~kg} / \mathrm{m}^{2}$ (Fernandez-Abascal et al. 1995).

The soil is a Cambisol Dístrico (Forteza 1987) formed on tertiary materials of the upper Miocene, siliceous conglomerates and grades (Mapa Geológico de España 
1:50000; Anon. 1982). Soil analysis of the area after a fire shows an increase in $\mathrm{pH}$, although it remains around 5. The soil shows high structural stability (Valbuena 1995). The climate is subhumid Mediterranean. Temperature and rain gauge data were supplied by the National Meteorological Institute station in Cistierna (the nearest meteorological station, situated $20 \mathrm{~km} \mathrm{~N}$ of the study area). Annual precipitation varies from $645 \mathrm{~mm}$ to 991 $\mathrm{mm}$; average maximum temperature varies between $28.5^{\circ} \mathrm{C}$ in August and $7.3^{\circ} \mathrm{C}$ in January and average minimum from 9.9 in August to $-4^{\circ} \mathrm{C}$ in January. There is a dry period in the summer.

\section{Burning and Soil sampling}

Four plots measuring $10 \mathrm{~m} \times 18 \mathrm{~m}(\mathrm{~A}, \mathrm{~B}, \mathrm{C}, \mathrm{D})$, with a $5 \mathrm{~m}$ wide corridor in between, were burned experimentally in July 1993. Before (control) and after experimental burning, four soil samples from each plot were collected from subplots, measuring $20 \mathrm{~cm} \times 25 \mathrm{~cm} \times 5 \mathrm{~cm}$, before the fire (BF) and after it (AF). Each sample was divided into two layers at the time of sampling: $0-2 \mathrm{~cm}$ ( $\mathrm{U}=$ upper layer) and $2-5 \mathrm{~cm}(\mathrm{~L}=$ lower layer $)$. The total number of samples was 64 (16 from each layer before and after burning).

\section{Culture conditions}

The soil samples were placed over sterile compost on culture trays $(36 \mathrm{~cm} \times 26 \mathrm{~cm} \times 4 \mathrm{~cm})$ in a laboratory without modifying the ambient temperature, subjected to a natural photoperiod and watered daily to keep the samples moist. Humidity in the laboratory varied between 40 and $70 \%$ and temperature between 14 and $20^{\circ} \mathrm{C}$ in autumn going down to $12^{\circ} \mathrm{C}$ in winter and reaching 38 ${ }^{\circ} \mathrm{C}$ in spring and summer. The trays were treated with the fungicide 'benlate' (Benomyl) to prevent the appearance of fungi without affecting seed germination.

Seedling emergences were recorded every three days for the first three months and every seven days thereafter for a period of 12 months. Each seedling that appeared was marked with a number to avoid counting errors. The seedlings were transplanted to encourage growth and make identification easier on reaching maturity.

\section{Vegetation sampling before and after the fire}

The species present in the existing vegetation were recorded ten days before the fire in each of the established plots. 20 random inventories, with a $1-\mathrm{m}^{2}$ quadrat were used to do this. The cover of species present was recorded for each quadrat.

For the study of post-fire recovery a single sampling was carried out, 10 months after the fire. Five quadrats of $1 \mathrm{~m}^{2}$ were recorded in each of the plots in a place beside that from which the seed bank sample had been taken. In addition to recording the cover of the species present it was also noted whether the plants came from seeds or sprouts in each quadrat.

\section{Data analysis}

Two Way Analysis of Variance was performed to detect the differences between the treatments. The samples taken from each plot were considered as a whole. Therefore, four replicates $\left(0.2 \mathrm{~m}^{2}\right.$ each $)$ were taken into account. Results with a probability higher than $P>0.05$ were considered as not statistically different.

\section{Results}

\section{Pre-fire situation}

In spite of the large number of species appearing before fire (richness 36 species in the studied plots) only a few had considerable mean cover in each of the plots (Table 1). The predominant ligneous species were Arctostaphylos uva-ursi, Erica australis and Calluna vulgaris. Amongst the herbaceous species Luzula lactea, Festuca rubra and Agrostis capillaris were predominant.

\section{Erica australis and Calluna vulgaris seed bank}

The seed bank of both species belong to group IV in the Thompson \& Grime classification (1979), that is,

Table 1. Mean $(\bar{X})$ and standard deviation $(s)$ of cover values $(\%)$ of the main vascular plants appearing in the experimental plots before the fire and 10 months after the fire. $(\mathrm{S}=$ plant from seedling, $\mathrm{R}=$ plant from resprout).

\begin{tabular}{|c|c|c|c|c|c|}
\hline & \multicolumn{5}{|c|}{ Before fire 10 months after fire } \\
\hline & $\bar{X}$ & $s$ & $\bar{X}$ & $s$ & $\begin{array}{r}\text { Regen. } \\
\text { Form }\end{array}$ \\
\hline Arctostaphylos uva-ursi & 55.02 & 17.00 & 0.68 & 0.31 & $\mathrm{R}$ \\
\hline Erica australis & 48.64 & 15.55 & 0.81 & 0.48 & R-S \\
\hline Calluna vulgaris & 23.54 & 13.35 & & & \\
\hline Halimium alyssoides & 5.79 & 6.09 & 0.56 & 0.83 & R-S \\
\hline Genistella tridentata & 4.14 & 1.17 & 0.37 & 0.44 & $\mathrm{R}$ \\
\hline Halimium umbellatum & 1.00 & 1.27 & & & \\
\hline Luzula lactea & 2.39 & 1.55 & 6.25 & 4.38 & R-S \\
\hline Agrostis capillaris & 1.90 & 2.46 & & & \\
\hline Festuca rubra s.l. & 1.21 & 1.41 & 1.93 & 4.96 & $\mathrm{R}$ \\
\hline Avenula marginata & 1.16 & 1.00 & 0.50 & 0.81 & $\mathrm{R}$ \\
\hline Deschampsia flexuosa & 0.92 & 1.74 & 1.43 & 2.70 & $\mathrm{R}$ \\
\hline Arenaria montana & 0.73 & 0.63 & 1.62 & 0.78 & $\mathrm{~S}$ \\
\hline Total number of species & & & & & \\
\hline No of spp. from seed & & & & & \\
\hline No of spp. from resproutir & & & & & \\
\hline No of spp. from seed and & outing & & & & 5 \\
\hline
\end{tabular}


Table 2. Complete list of species, their biological traits and the number of individual plants appearing in the seed bank samples from each site. $X=$ mean of the plots; $s=$ standard deviation. Sampling areas: UBF $=$ Upper before fire layer; $\mathrm{LBF}=\mathrm{Lower}$ before fire layer; $\mathrm{UAF}=$ Upper after fire layer; $\mathrm{LAF}=$ Lower after fire layer. ${ }^{*}$ Unidentified species. Biological traits $(\mathrm{BT}): \mathrm{P}:$ Perennial, A: Annual, BA: Biennial, H: Herbaceous, W: Woody Life Forms (LF): He: Hemicryptophyte, C: Chamaephyte. Seed Dissemination Types: A: Autochory; B: Barochory; V: Anemochory.

\begin{tabular}{|c|c|c|c|c|c|c|c|c|c|c|c|}
\hline & \multicolumn{2}{|c|}{ UBF } & \multicolumn{2}{|c|}{$\mathrm{LBF}$} & \multicolumn{2}{|c|}{ UAF } & \multicolumn{2}{|c|}{ LAF } & \multirow[b]{2}{*}{ B.T. } & \multirow[b]{2}{*}{ L.F. } & \multirow[b]{2}{*}{ Seed Diss. } \\
\hline & $X$ & $s$ & $X$ & $s$ & $X$ & $s$ & $X$ & $s$ & & & \\
\hline Number of seedlings & 377.0 & 87.6 & 140.2 & 76.8 & 240.5 & 100.6 & 169.5 & 71.2 & & & \\
\hline Erica australis & 338.2 & 75.1 & 118.7 & 77.2 & 111.5 & 57.2 & 124.0 & 64.2 & P-W & $\mathrm{C}$ & $\mathrm{V}$ \\
\hline Calluna vulgaris & 13.5 & 12.0 & 4.5 & 9.0 & 114.3 & 41.6 & 23.7 & 10.3 & P-W & $\mathrm{C}$ & $\mathrm{V}$ \\
\hline Arenaria montana & 18.5 & 13.3 & 14.0 & 9.4 & 11.7 & 7.0 & 15.7 & 13.7 & $\mathrm{P}-\mathrm{H}$ & $\mathrm{He}$ & A \\
\hline Genistella tridentata & 0.3 & 0.5 & 0.3 & 0.5 & 1.3 & 1.3 & 0.5 & 1.0 & P-W & $\mathrm{C}$ & A \\
\hline Lotus corniculatus & & & & & 1.0 & 2.0 & 2.3 & 3.3 & P-H & $\mathrm{He}$ & $\mathrm{B}$ \\
\hline Hypericum humifusum & & & 0.5 & 1.0 & & & & & BA-H & $\mathrm{He}$ & $\mathrm{A}$ \\
\hline Halimium alyssoides & & & 0.3 & 0.5 & & & & & $\mathrm{P}-\mathrm{W}$ & $\mathrm{C}$ & A \\
\hline *Gramineous species & 6.5 & 3.1 & 2.0 & 2.2 & 0.8 & 1.0 & 3.3 & 2.6 & $\mathrm{P}-\mathrm{H}$ & $\mathrm{He}$ & V \\
\hline
\end{tabular}

ligneous shrubland species with persistent seed banks. Throughout the study period a total of 2770 Erica australis and 624 Calluna vulgaris seedlings were counted. A greater number of seedlings of these species was from samples of the upper layer $(0-2 \mathrm{~cm})$ than the lower one, except in the case of Erica australis after burning (Table 2). From these results, the number of Erica australis seedlings $/ \mathrm{m}^{2}$ was estimated taking the surface area into consideration: 2285 germinable seeds $/ \mathrm{m}^{2}$ before burning and 1177 germinable seeds $/ \mathrm{m}^{2}$ after the fire.

The number of seedlings appearing in the upper layer $(0-2 \mathrm{~cm})$ after the fire decreased in relation to the samples before the fire, but that was increased slightly in the lower layer. The decrease may be due to mortality caused by the high temperatures reached in the first few $\mathrm{cm}$ of the soil. The number of Erica australis seedlings appeared in the $0-2 \mathrm{~cm}$ layer was significantly greater $(P<0.05)$ than that of the $2-5 \mathrm{~cm}$ pre-burn samples, but after the fire there was no difference in seedling number between the two layers. No difference in germinable seeds was observed in the $2-5 \mathrm{~cm}$ layer in the samples of before and after the experimental fire. However, there was a significantly larger number of seedlings in the upper layer in the samples before the fire than afterwards.

Calluna vulgaris had 90 germinable seeds $/ \mathrm{m}^{2}$ in the control samples (before the fire) but the estimated number of seeds in the bank after the fire was 690 seeds $/ \mathrm{m}^{2}$. On comparing the number of seedlings appearing before and after the fire as well as by layers, statistically significant differences $(P<0.05)$ between the upper layers before and after the fire and between upper and lower layers in the burnt area were observed; on the contrary, there are no significant differences between the lower layers before and after the fire.

Differences in the total seedling number appearing in the samples taken before and after the fire were not detected. When seedling number by layers was com- pared, statistically significant differences $(P<0.05)$ were only observed in the control.

\section{Seedling appearance throughout the study period}

Erica australis has a small peak two months after beginning of the experiment in the samples from the lower layer after the fire (Fig. 1). For the samples collected on the surface before the fire, the germination peak
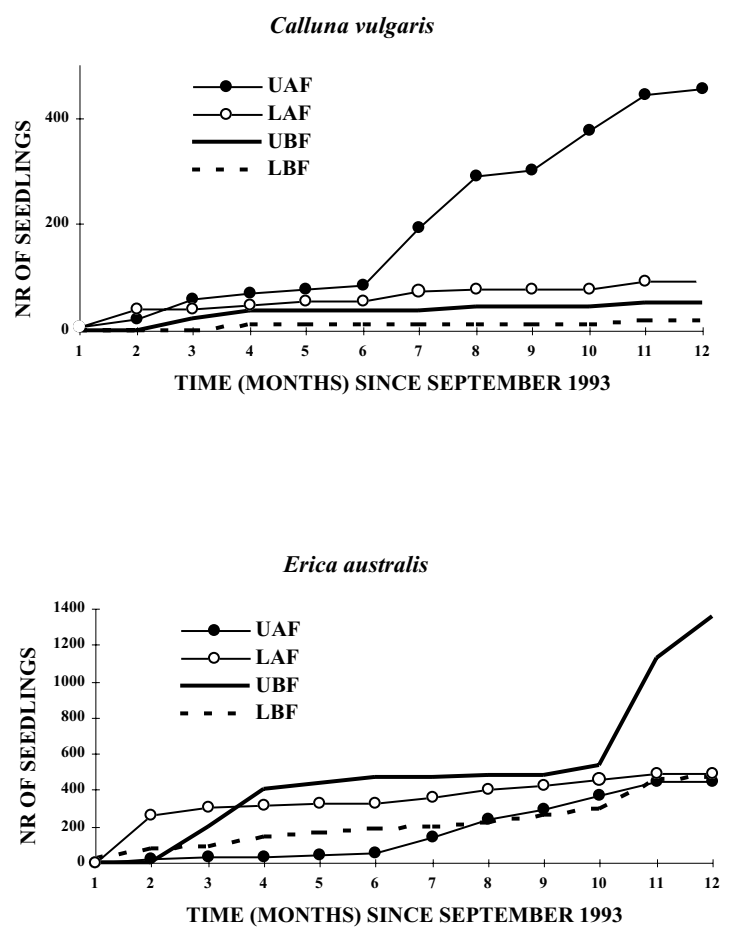

Fig. 1. Cumulative number of seedlings appearing in the samples during the study period. $(\mathrm{UBF}=\mathrm{Upper}$ layer before fire; $\mathrm{LBF}=$ Lower layer before fire; UAF = Upper layer after fire; $\mathrm{LAF}=$ Lower layer after fire). 
is 11 months after the experiment started. Calluna vulgaris emerges throughout the study period (Fig. 1); the maximum is found in the upper layer of the burned area, seven months after the experimental fire.

\section{Recovery in the field}

In the field, of 28 species found 10 months after the fire 17 were from seeds (Table 1) and five from both seeds and resprout. However, only six species appeared from the seed bank in the samples taken after the fire (Table 2). Moreover, neither seedlings nor sprouts of Calluna vulgaris were present ten months after the fire, which may be due to the absence of germination or $100 \%$ mortality. Erica australis had sprouted and also, though to a lesser degree, seedlings had appeared, although mean cover percentage was still only $0.8 \%$. Even after the fire the Erica australis soil seed bank is large (555 seedlings $/ \mathrm{m}^{2}$ in the samples from the upper layer). However, most post-fire recovery is from vegetative resprouting in the field with only a very few seedlings being observed, with negligible cover.

\section{Discussion}

The higher number of seedlings observed in the upper layer is according to the results of most of the authors (Bigwood \& Inouye 1988; Archibold 1989; Legg et al. 1992). The temperatures reached during the fire improved the germinability of Calluna vulgaris seeds, the opposite occurring with Erica australis seeds. These results coincide with those recorded in laboratory test by Mallik \& Gimingham (1985) and GonzalezRabanal \& Casal (1995), which found that germination of Calluna vulgaris is favoured by the rise in temperature, and by Luis-Calabuig et al. (2000) which obtained lower germination levels in Erica australis seeds when they were submitted to heating. In both species, differences between pre- and post-fire seedling number were only appreciated in the upper layer. This is probably due to the decrease in temperature as soil depth increases. Although high temperatures can be reached sporadically in the lower layer, the mean temperature was about $30^{\circ} \mathrm{C}$ and it has no effect on the seeds (Valbuena 1995).

The slow germination dynamics in the studied seed bank samples were in agreement with the results obtained in laboratory experiments, where it was observed that Ericaceae seeds suffer from a considerable delay from placement in ideal conditions to the start of germination (Valbuena unpubl.). The delay in appearing after a fire may be due, in part, to the appearance of secondary dormancy which occurs in some seeds. On the other hand, germination of the seeds in the samples collected after the fire may be inhibited by the existence of ash in the sample; Gonzalez-Rabanal (1993), for example, states that ash water completely inhibits the germination process. The inhibition could be progressively removed by leaching when daily watering and then seed germination commences. However, aspects stimulating seed germination are still little understood, as stated by Bond \& van Wilgen (1996).

The appearance of seeds germinating from withering flowers of Erica australis was observed. This confirms the importance of flowers dispersed by the wind and which retain seeds inside. This may be important for the dispersion distance of this species, an idea already stated by Legg et al. (1992) for Calluna vulgaris.

Although this species reproduces mainly by sprouting, a large number of Erica australis seeds were found. Many authors state that sprouting species have a smaller number of seeds and retain smaller seed banks than nonsprouting ones (Keeley 1986; Enright \& Lamont 1989). However, Arroyo \& Herrera (1988), and Cruz (1996) also point out the high production of seeds in Erica australis. The observed density of Calluna vulgaris seedlings in the soil seed bank was lower than the average registered by most authors working in heathlands where this species was dominant (Thompson et al. 1997).

Two years after the fire Calluna vulgaris had not yet appeared, whilst Erica australis had recovered very well with resprouts although recolonization from seeds is negligible (Fernández et al. 1996). This, at least as far as Calluna vulgaris is concerned, is contrary to what other authors have recorded. For example, Miller \& Cummins (1987) maintain that Calluna vulgaris is a species that can remain in a dormant state in the soil for several years, which means that the seed bank's role in population recovery after disturbance is important. Pons (1989) stated that seeds of this species respond well to dehydration periods and are also benefited by light, thus germinating more easily in the case of disturbance. However, Vera \& Obeso (1995), who studied an Atlantic heath, observed that Calluna vulgaris only appeared as a seedling two years after fire and never as a resprout, and Calvo et al. (1992) did not detect this species during four years after experimental disturbances in a heathland close to the study area. The reason for this delay in recovery response is not clear. It is generally considered that seeds of this species have a large variability and that there are very many micro-environmental factors affecting germination (Gimingham 1972; Mallik et al. 1984; Lavorel 1987).

It may be concluded that Erica australis seeds existing in the soil have been damaged by the high temperatures in the upper layer whilst those of Calluna vulgaris are favoured. As far as recovery of these species by seed in the area is concerned, very special microclimatic conditions may be necessary for this to be possible. 
Acknowledgements. The authors wish to thank the staff of Centro de Investigaciones Forestales de Lourizán (Pontevedra) for their help with the experimental burning. This paper is part of a research project suported by the C.I.C.Y.T.

\section{References}

Anon. 1982. Mapa Geológico de España 1:50.000. Edita Servicio de Publicaciones del Ministerio de Industria y Energía. Base Topográfica del Servicio Geográfico del Ejercito. Serie M-781, Madrid.

Anon. 1984. Mapas de cultivos y aprovechamientos de la provincia de León. Dirección General de Producción Agraria, Madrid.

Archibold, O.W. 1989. Seed bank and vegetation processes in coniferous forests. In: Leck, M.A., Parker, V.T. \& Simpson, L.M. (eds.) Ecology of soil seed banks. Academic Press, Inc. New York, NY.

Arroyo, J. \& Herrera, J. 1988. Polinización y arquitectura floral en Ericaceae de Andalucía Occidental. Lagascalia 15: 615-623.

Bakker, J.P. 1989. Nature management by grazing and cutting. Kluwer, Dordrecht.

Belhassen, E., Pomente, D., Trabaud, L. \& Gouyon, P.H. 1987. Récolonisation après incendie chez Thymus vulgaris (L.): Resistence des graines aux temperatures élevées. Acta Oecol. Oecol. Plant. 8 (22): 135-141.

Bigwood, D. \& Inouye, D.W. 1988. Spatial pattern analysis of seed banks: an improved method optimized sampling. Ecology 69: 497-507.

Bond, W.J. \& van Wilgen, B.W. 1996. Fire and plants. Chapman \& Hall, New York, NY.

Calvo, L., Tárrega, R. \& Luis, E. 1992. The effect of human factors (cutting, burning and uprooting) on experimental heathland plots. Pirineos 140: 15-27.

Cruz, A. 1996. Factores que controlan la capacidad de rebrote de Erica australis L. Tesis Doctoral. Univ. Complutense de Madrid.

Debussche, M., Escarre, J. \& Lepart, J. 1980. Changes in mediterranean shrub communities with Cytisus purgans and Genista scorpius. Vegetatio 48: 73-82.

Enright, N.J. \& Lamont, B.B. 1989. Seed banks, fire season, safe sites and seedling recruitment in five co-occurring Banksia species. J. Ecol. 77: 1111-1122.

Fernández-Abascal, I., Tárrega, R. \& Luis-Calabuig, E. 1995. Comparison of biomass post-fire recovery in heathlands. $5^{\text {th }}$ European Heathland Workshop. Santiago de Compostela.

Fernández-Abascal, I., Valbuena, L., Luis-Calabuig, E. \& Tárrega, R. 1996. The effects of sowing natives species in recovering heathland subjected to prescribed burning. 1er Congreso Europeo sobre el Control de la Erosión. Sitges (Barcelona).

Forteza, J. 1987. Mapa de suelos de Castilla y León. Consejería de Fomento. Junta de Castilla y León.

García-Novo, F. 1977. The effects of fire on the vegetation of Doñana National Park. (Spain). In: Proceedings of the Symposium on the Environmental Consequences of Fire and Fuel Management in Mediterranean Ecosystems. Palo Alto, CA.

Gimingham, C.H. 1972. Ecology of heathlands. Chapman and Hall, London.

Gonzalez-Rabanal, F. 1993. Efecto del fuego sobre la germinación de especies de ecosistemas de matorral. Tesis Doctoral, Universidad de Santiago de Compostela.

Gonzalez-Rabanal, F. \& Casal, M. 1995. Effect of high temperatures and ash on germination of ten species from gorse shrubland. Vegetatio 116: 123-131.

Jiménez, H.E. \& Armesto, J.J. 1992. Importance of the soil seed bank of disturbed sites in Chilean matorral in early secondary succession. J. Veg. Sci. 3: 579-586.

Keeley, J.E. 1986. Resilience of mediterranean shrub communities to fires. In: Dell, B., Hopkins, A.J.M. \& Lamont, B.B. (eds.) Resilience in mediterranean-type ecosystems, pp. 95-112. Junk, Dordrecht.

Keith, D.A. \& Bradstock, R.A. 1994. Fire and competition in Australian heath: a conceptual model and field investigations. J. Veg. Sci. 5: 347-354.

Lavorel, S. 1987. Etude de la plasticité phenotypique chez Calluna vulgaris (L.) Hull. Diplôme d'Etudes Approfondies en Sciences de l' Evolution et Ecologie. Academie de Montpellier. Universite des Sciences et Techniques du Languedoc.

Lavorel, S., Lebreton, J.D., Debussche, M. \& Lepart, J. 1991. Nested spatial patterns in seed bank and vegetation of Mediterranean old-fields. J. Veg. Sci. 2: 367-376.

Legg, C.J., Maltby, E. \& Proctor, M.C.F. 1992. The ecology of severe moorland fire on the North York Moors: seed distribution and seedling establishment of Calluna vulgaris. J. Ecol. 80: 737-752.

Luis-Calabuig, E., Tárrega, R. \& Zuazua, T. 1987. Shrub responses to experimental fire. First phases of regeneration. Ecol. Medit. 13 (4) 155-162.

Luis-Calabuig, E., Tárrega, R., Zuazua, T. \& Calvo, L. 1989. Proyecto I + D 10/84 Agroenergética: comunidades de matorral. Opt. Médit. Sér. Sémin. 3: 131-135.

Luis-Calabuig, E., Tárrega, R., Calvo, L., Marcos, E. \& Valbuena L. 2000. History of landscape changes in northwest Spain according to land use and management. In: Trabaud, L. (ed.) Life and enviroment in Mediterranean ecosystems, pp. 43-86. Wit Press, Southampton.

MacDonald, N. \& Watkinson, A.R. 1981. Models of an annual plant population with a seed bank. J. Theor. Biol. 93: 643653.

Mallik, A.U. \& Gimingham, C.H. 1983. Regeneration of heathland plants following burning. Vegetatio 53: 45-58.

Mallik, A.U. \& Gimingham, C.H. 1985. Ecological effects of heather burning. II. Effects on seed germination and vegetative regeneration. J. Ecol. 73: 633-644.

Mallik, A.U., Hobbs, R.J. \& Legg, C.J. 1984. Seed dynamics in Calluna-Arctostaphylos heath in north-eastern Scotland. J. Ecol. 72: 855-871.

Mazzoleni, S. \& Pizzolongo, P. 1990. Post-fire regeneration patterns of Mediterranean shrubs in the Campania region, Southern Italy. In: Goldammer, J.G. \& Jenkins, M.J. (eds.) Fire in ecosystem dynamics, pp. 43-51. SPB Academic Publishing, The Hague. 
Miller, G.R. \& Cummins, R.P. 1987. Role of buried viable seeds in the recolonization of disturbed ground by heather (Calluna vulgaris (L.) Hull) in the Cairngorm Mountains, Scotland, U.K. Arct. Alp. Res. 19: 396-401.

Naveh, Z. 1974. Effects of fire in the Mediterranean region. Kozlowski, T.T. \& Ahlgren, C.E. (eds.) Fire and ecosystems, pp. 401-434. Academic Press, New York, NY.

Pacala, S.W. 1986. Neighborhood models of plant population dynamics. 4. single species and multispecies models of annuals with dormant seeds. Am. Nat. 128: 859-878.

Pons, T.L. 1989. Dormancy and germination of Calluna vulgaris (L.) Hull and Erica tetralix L. seeds. Acta Oecol. Oecol. Plant. 10: 35-43.

Thompson, K. \& Grime, J.P. 1979. Seasonal variation in the seed banks of herbaceous species in ten contrasting habitats. J. Ecol. 67: 893-921.
Thompson, K., Bakker, J. \& Bekker, R. 1997. The soil seed banks of North West Europe: methodology, density and longevity. Cambridge University Press, Cambridge.

Trabaud, L. 1987. Fire and survival traits of plants. In: Trabaud, L. (ed.) The role of fire in ecological systems, pp. 65-89. Academic Publishing, The Hague.

Trabaud, L. 1994. Diversité de la banque de semences du sol d'une fôret Méditérranéenne de Quercus ilex. Biol. Conserv. 69: 107-114.

Tutin, T.G. et al. 1964-1980. Flora Europaea. Cambridge University Press, Cambridge.

Valbuena, L. 1995. El banco de semillas del suelo y su papel en la recuperación de comunidades incendiadas. Tesis Doctoral. Universidad de León (España).

Vera, M.L. \& Obeso, J.R. 1995. Regeneración del Brezal atlántico de Cabo de Peñas después de un incendio severo. Studia Oecol. 12: 223-236.

Received 9 June 1998; Revision received 18 January 1999; Final version received 10 November 1999; Accepted 10 November 1999. Coordinating Editor: J.P. Bakker. 